\title{
Qatar's Clean Diplomacy Facing Regional Conflict
}

Alfredha Shinta Putri ${ }^{1}$, Surwandono ${ }^{2}$ alfredha.shinta@yahoo.com ${ }^{1}$,surwandono@umy.ac.id ${ }^{2}$

${ }^{1}$ Master of International Relations Department, University of Muhammadiyah Yogyakarta, JL. Brawijaya, Kasihan, Bantul, Yogyakarta 55183, Indonesia

\begin{abstract}
Qatar is one of the richest countries in the Middle East region. Qatar is able to supply the third largest gas to the world and become the third largest exporter of liquid natural gas. This paper is interested in analyzing the behavior of the Qatari government amid various conflicts and tensions in the Middle East region. Qatar tends to position itself as a mediator of conflict. The Qatari government believes that by being a mediator in this conflict it can be a neutral position.Qatari governance is based on the basic norm structure that is used as a policy platform, and articulates it openly, with integrity, and is measurable. This is known as clean diplomacy. Qatar manages the crisis by remaining consistent with its image as a guardian of regional peace and stability. The image of Qatar as an 'honest broker' country is able to increase Qatar's legitimacy in the international public arena. This paper builds on arguments based on secondary document data, and interprets the data with a qualitative approach to understanding Qatar's foreign policy behavior. The analysis showed that the choice of governance of Qatar's clean diplomacy proved effective in managing the foreign political pressure of neighboring countries in the form of not escalating conflict, and Qatar's political and economic stability.
\end{abstract}

Keywords: Clean Diplomacy, Conflict, Foreign Policy, Qatar

\section{Introduction}

Qatar can be called a rising power in the 21 st century. Having a population of only around 250,000 people with very limited military capabilities, Qatar is a constitutional monarchy system controlled by the Al-Thani family regime (Blanchard, 2014). Qatar emerged as a global player with a new form (Felsch, 2016). Qatar is one of the richest countries in the Middle East region. Qatar is able to supply the third largest gas to the world and become the third largest exporter of liquid natural gas. With a small population, they can feel a very high income per capita. There are so many roles in Qatar in the sports field, for example as he has a circuit for the MotoGP and Formula 1 event. Although as a small country, Qatar can hold a "sports party" of that size. In addition to being a wealthy country, Qatar also tries to give women and women the opportunity to vote in elections (Mitchell, 2014).

This paper is interested in analyzing the behavior of the Qatari government amid various conflicts and tensions in the Middle East region. Qatar tends to position itself as a mediator of conflict. The Qatari government believes that by being a mediator in this conflict it can be a neutral position. Qatar always tries to open line of communication for any conflictual parties. The foreign policy strategy chosen by the Qatari government is called the clean diplomacy strategy. It argues that negotiations is held in a transparent, fair and open manner. Diplomacy is expected to provide benefits for the parties involved. So that diplomacy is resulting a positive sum game. In addition, 
a clean diplomacy strategy becomes a rational choice for the Qatari government by considering its position as a small countries to face the interests of major powers.

Qatar is a unique country globally and its size. He became a prolific and visible mediator. Despite its status as a small country, Qatar has a good geo-strategic position. As a small country, it also seeks to secure its position and strive to have an "important" position in the international world, especially the Middle East region. So of course he has his own strategy and ways to practice his diplomacy so that he is free from the threat and pressure of the big powers. As a small country, it tries to be neutral and has no alliances with any state. In addition, Qatar has also become a neutral mediator in a dispute of both international and regional nature, particularly in the Middle East region.

Today, Qatar has experienced several problems and crises both at home and with neighboring countries. The Qatar crisis was marked by the severance of diplomatic relations, namely the withdrawal of ambassadors, embargoes and travel restrictions. The countries that sever diplomatic relations with Qatar are Saudi Arabia, the United Arab Emirates, Bahrain, the Maldives, Yemen and Egypt. Then, the countries that reduced the level of diplomatic relations with Qatar were Chad, Djibouti, Eritrea, Jordan, Senegal and Nigeria (Jones, Lynch, Roberts, \& Diwan, 2017).

Lots of restrictions and restrictions are imposed by Saudi Arabia, the United Arab Emirates, Bahrain and the Maldives. Examples such as Saudi Arabia and the United Arab Emirates to restrict and ban Qatari ships from entering their ports. Then Saudi Arabia closed the border with Qatar, restricted airspace, and urged Saudi Arabian banks not to conduct transactions with Qatar banks. Then these countries blocked Qatar media like Al-Jazeera. As a result of the Qatar crisis, Qatar has experienced a drastic decline in per capita income. Qatar shares plummeted and are at the lowest level.

On June 5, 2017, a coalition of countries led by Saudi Arabia announced an embargo on Qatar. Some countries are fellow members of the Gulf Cooperation Council with Qatar who take embargo action to fight close allies. The reason given for embargoing is that Qatar is suspected of supporting terrorist acts, but the public explanation does not specify the specifics of what the government has done in Doha. When the crisis took place, the Saudi-led coalition continued to provide news to the press, but there were no further details and the explanation sometimes made no sense (Harlow, 2017). Regarding Arab embargo policy on Qatar's economy, it will certainly have an impact on Qatar's economy. The impact of the embargo could affect world oil, commercial flights, shipping, food, markets, stocks, finance, insurance, and banks, transportation, trade.

Doing so will certainly provide opportunities at the regional level to develop inclusive regional frameworks for mediation and negotiation as well as in effective security communities. Broadly defined, a security community exists when sovereign 
states can overcome a lack of mutual trust and a difficult regional environment to develop new forms of cooperative security that prioritize self-control and peaceful resolution of differences and reduce hopes for resorting to violent organizations. to resolve disputes between states (Miller, 2019).

Geography and anarchist state systems provide incentives for the United Arab Emirates (UAE) and Qatar to collaborate in managing the threats posed by being neighbors of the two regional hegemony of Saudi Arabia and Iran. Geography and anarchist state systems provide incentives for the United Arab Emirates (UAE) and Qatar to collaborate in managing the threats posed by being neighbors of the two regional hegemony of Saudi Arabia and Iran. However, the two small countries responded very differently to the causes and consequences of instability in the Gulf region and developed very different foreign policies to deal with the structural problems of their international relations. How different their external relations are now can be seen clearly in the UAE's leading role in the diplomatic boycott and economic embargo launched against Qatar in June 2017, including the de facto dissolution of the Gulf Cooperation Council (Miller \& Verhoeven, 2019)

The influx of petroleum revenues brought about by the 1973-1974 oil embargo led to a dramatic expansion of modernization efforts in the newly independent Qatar emirate to include the first physical manifestation of modern national identity in its capital, Doha. Among these efforts was the creation of 'New Doha', whose development included a design competition for the central government complex, namely the offices of Kenzo Tange, James Stirling, Collaborative Architects and Günter Behnisch (Himes, 2018).

GCC's contribution as a conflict mediator is able to examine the institutional structure and sub-regional group policy approaches. First, the GCC was designed as a mediator of conflict, bearing in mind that the Arab Gulf states created it as a motor to respond to intra-Gulf and external security threats and challenges. Second, in order to promote the independence of its foreign policy and enhance its regional and global diplomatic profile, the Qatari government ensures its security and survival in a dangerous environment in the Gulf region. Qatar has widely sought to mediate conflicts in Lebanon, Yemen and Sudan, with varying degrees of success under the GCC and the Arab League banners (Nuruzzaman, 2015).

One of the backgrounds of these countries was to break diplomatic relations with Qatar because the Qatari government was accused of supporting acts of international terrorism. The Qatari government is suspected of funding several rebel groups in the Middle East. In addition, the Qatari government is also suspected of disturbing the stability of the Middle East Region and seeking to improve relations with Iran. For Saudi Arabia, Qatar is too open and free to use Al-Jazeera's media. Negative news about Saudi Arabia was highly exposed by Qatar in the Al-Jazeera media. In addition to Bahrain and the United Arab Emirates, Qatar is seen as 
interfering in their domestic affairs. This is indicated by the large number of Muslim Brotherhood members in their countries (Zafirov, 2017).

With this condition, it can be difficult for Qatar, because they feel that they are isolated by countries around the Middle East region. With this policy, Qatar turned into a country that is very active in diplomacy in regional conflicts, investing in international companies, being able to control the Arab news channel Al-Jazeera, and being able to host the FIFA World Cup 2022. Qatar is able to change himself in the global hub and central pivot of globalization (Felsch, 2016). Before he changed to what he is today, he used to have the nickname of sleepy fishing town, but now Qatar is able to become one of the clubs of the regional great power. Qatar is a small country, but has a "big politic". Qatar benefits from the security and financial situation to increase regional influence. Qatar is able to show that even small countries have the capability to influence world politics. Qatar also became an important actor in the early Arab Spring. Qatar is able to build an attractive image as a front line in stability and prosperity.

Seeing the crisis and problems faced by Qatar, although as a small country, Qatar is not afraid of facing various problems. With the plummeting stock conditions and low per capita income, he is still able to withstand embargoes and restrictions imposed by neighboring countries. Qatar is not too turbulent with the existing conditions and situations. It can be said that Qatar is a small country that is opposed collectively by large countries. Although he is a small country, he is able to survive the conditions isolated by neighboring countries, namely Saudi Arabia, Bahrain, Yemen, and Egypt. Surely this is very interesting to study what kind of diplomacy strategies and foreign policies adopted by Qatar as a small country (Zafirov, 2017).

\section{Literature Review}

Clean diplomacy is diplomacy that is free from deviations, meaning that the implementation of diplomacy must be in accordance with the ideals. Clean diplomacy means that the implementation of matters relating to diplomacy is done openly, in accordance with applicable rules and norms, and refers to governance in international relations. The implementation of diplomacy must prioritize the interests of the people rather than their elites, egalitarian principles, and fairness. Clean diplomacy always teaches about being egalitarian and fair. Islam always teaches the equality of all human beings in accordance with the guidance of the Qur'an. All humans have the same rights and obligations. Islamic International Law offers the regulation of the rules of Muslim countries with the most fair formula (Warsito \& Surwandono, 2015). Clean negotiations in diplomacy must be accountable, open, transparent and fair both for oneself and others' interests.

Small countries that have implemented clean diplomacy governance are Switzerland and Singapore. Swiss foreign policy is based on self-image that Switzerland 
is in a geographical area that is vulnerable to regional and international conflicts. Switzerland tries to actively participate in the arena of international politics and join international organizations (Gabriel \& Fischer, 2003). Switzerland faces an interesting dualism. First, both economically, culturally, and scientifically, Switzerland is interdependent internationally. When talking about low politics, Switzerland is very enthusiastic about it in the international world. However, when talking about issues of high politics, Switzerland always talks about it in the local (domestic) arena. Switzerland is a country that is excellent globalizers and free traders in certain areas, but becomes a perfect isolationists and protectionists in other fields.

The combination of the Swiss political system namely federalism, collegiality, concordance, and direct democracy is able to bring Switzerland to have a very strong and unique system. Swiss foreign policy, can be seen as a useful instrument for defending the Swiss political system from outside attacks. In matters of foreign policy, Switzerland is sovereign and neutral. There is a very strong relationship between domestic and foreign politics of the Swiss state, which in turn results in Switzerland finding it difficult to adjust to changes in the international. Switzerland is neutral and can be characterized by national defense, military intermediaries, and good offices. In armed neutrality, Switzerland implements autonomous national defense as the core of Switzerland's traditional foreign and security policies. Neutrality and autonomous defense are synonymous with Switzerland. In particular Switzerland also approaches directly with American hegemony (Gabriel \& Fischer, 2003).

Singapore is a small country and has a small population. $3 / 4$ The population in Singapore is Chinese, 14\% are Malay, and 8\% are South Asian origin. Singapore is said to be a fragile society and not a nation (Leifer, 2000). Singapore builds a self-image of foreign policy by increasing diplomatic relations with 158 countries in the world very well, even with limited human resources. This is because there is a potential domestic fragility and limited geographical location, so this forms the worst-case in developing Singapore's foreign policy. Singapore has an extraordinary natural harbor, where it occupies a strategic location at the crossroads between the Indian Ocean and the Pacific. It has become the world's busiest port in the world. Singapore has been able to develop a promising economic performance since its independence, which has transformed traditional entrepreneurship into a modern global version. Singapore is active in three important networks of intra-regional multilateral diplomacy namely, the Association of South-East Asian Nations (ASEAN), the Asia-Pacific Economic Cooperation (APEC), and the ASEAN Regional Forum (ARF). He was also involved in transregional dialogue between Asia and Europe, and the Asia-Europe Meeting (ASEM)(Low, 2002).

The economic success experienced by Singapore has given him the resources to build modern defense capabilities beyond the capabilities of nearby neighbors. Singapore's defense budget is fairly constant at around 5\% of GDP. So this has made 
it possible to procure the most modern equipment. Despite its economic and diplomatic achievements as well as its defense capabilities, Singapore is a country whose foreign policy is rooted in culture of siege and insecurity stemming from a traumatic experience of unexpected separation from Malaysia in August 1965. "Antagonism" together with Indonesia and Malaysia has become the main political fear of the Singapore government to date. A "locked" geopolitical position at the southern tip of Peninsular Malaysia means that access by sea and air requires travel by sea and air in Indonesia and Malaysia (Leifer, 2000). Such a view is based on the belief that without access to balancing power, the biggest bully on the block will do what it wants.

Singapore has always tried to avoid involvement with the quarrel of the major powers for the sake of securing national interests. Singapore always puts forward the interests of national sovereignty. Diplomacy is used to manage relations with various governments for economic and security benefits. Singapore is trying to mobilize all its considerable diplomatic resources and energy as a way to reduce the vulnerabilities arising from geopolitical conditions. Considering that vulnerability, Singapore's foreign policy is not like other countries' policies in the matter of sovereignty. So this makes Singapore strive to establish external relations, which is Singapore's diplomatic power (Chong, 2006).

Singapore's foreign policy tends to deal with "vulnerability" caused by geopolitical positions. For this reason, Singapore's foreign policy has been widely informed as "the balance of power" (Leifer, 2000). Singapore will always try to establish very good relations with its neighbors, especially Indonesia and Malaysia for the sake of securing its national interests. Today Singapore is the "heart of the islands" in Malay / Indonesia (Lian Kwen Fee, 2001).

\section{Research methods}

This type of research used in this research is descriptive explanative nature. Descriptive research is a study that aims to obtain a picture of a certain time. The approach used in this research is a qualitative method. This is because the nature of this research is qualitative information. The qualitative method is research about research that is descriptive in nature and tends to use analysis. The process and meaning (subject perspective) is more highlighted in qualitative research. The theoretical foundation is used as a guide so that the focus of research is in accordance with the facts in the field. Besides this theoretical foundation is also useful to provide a general description of the research background and as a material discussion of research results. This study uses secondary data collection techniques using library materials such as journals, books, articles, and newspapers and uses library resources to establish continuity of data connectivity and analysis. 


\section{Results and Discussion}

Qatar is a small country in the Middle East region. Qatar is an emirate in the Middle East located on a small peninsula in the Arabian Peninsula in West Asia. Their only land border is Saudi Arabia in the south and the rest borders on the Persian Gulf. This bay also separates Qatar from the island nation of Bahrain. Qatar is a country with high economic income, supported by the world's third largest natural gas and oil reserves. This country is included in the highest per capita income country in the world. Qatar is classified as a country that has a very high human development index and is the best among other Arab countries. Qatar has a strong influence in the Arabian Peninsula and holds a significant influence in the world. There are several foreign policies carried out by Qatar in international politics. Qatar is trying to become an economic investor in the Middle Eastern and Western countries. This he did to build good relations between countries and strengthen social and political stability. Although he has very limited resources, he is able to build a sustainable development (Felsch, 2016). Qatar is more focused on the distribution of welfare for the population, creating a high education system, influencing through the media, carrot diplomacy, sport diplomacy, and foreign aid.

Qatar is very active in the diplomacy process. He is able to become an international actor who is very influential in the international world. to strengthen his influence in the international world, he does not use hard power (military), but uses soft power as the strength of Qatar. In Qatar's foreign policy it does emphasize that it is an active mediator in the process of conflict resolution between nations. Qatar wants to "compare" itself so that its role is needed in the process of conflict resolution in the international world (Kamrava, 2011). Mediation is a foreign policy, where it becomes a country's strategy in the domestic and international political system. Mediation is an effort from Qatar where it is used as a means to compare itself internationally.

The dilemma experienced by Qatar today is managed by capitalizing a number of resources owned by Qatar to continue to build connectivity with the international system. First, Qatar continues to be a country that participates in building world peace, placing itself as a neutral peacemaker in international and intra-national conflicts in the Middle East (Kamrava, 2011). In the conflict between Sudan, Yemen and Lebanon, Qatar was able to reduce tension between the three countries. by being a good mediator, this shows that Qatar is a neutral country both in the Middle East and internationally. Qatar always tries to open line of communication for the warring parties. Qatar places itself as a facilitator in dialogue and quite negotiation between warring countries, where these countries allow for direct communication (Ulrichsen, 2014). Qatar is able to facilitate neutrality among the warring parties.

Since 2000, Qatar has been an active mediator in the world both in regional and intra-national cases in the Middle East and Africa (Kamrava, 2011). Qatar imaged itself to be an honest broker in peace and stability. Despite being a small country, Qatar 
is very active in the process of conflict resolution in the international world. Qatar has an modus operandi in the process of conflict resolution in the regional environment. Doha's "niche diplomacy" has a reputation as a reliable peace broker. Before Qatar emerged as an active country as a mediator in conflict resolution, Egypt and Saudi Arabia were the mediators in conflict resolution. Qatar is able to prove a good track record as a mediator, as a regional diplomatic powerhouse, as an honest broker, a wise and mature player, where Qatar is able to create peace and stability.

In the mediation activities carried out by Qatar, the Qatari diplomats used interview media to present the country's positive effects. If the diplomacy process has been completed, they will continue the process to create a regional stability. Therefore, Qatar diplomacy is often referred to as niche diplomacy. Niche Diplomacy is a diplomacy that uses special political work. This diplomacy is often used by small countries who want to develop a profile of diplomacy with image-building (media and advertising) about them for certain reasons (Amini \& Akbarsefat, 2016). So they want to expand their image to civil society. In addition to being a good mediator in the region, as a rich country Qatar also provides an injection of funds (investment) for countries that are in conflict. For example, Qatar has invested in southern Lebanon and Sudan. Aside from being an investor in the Middle East region, he has also invested his money in the West such as Britain. All the processes undertaken by Qatar, both as mediators and in the diplomatic process, are as Qatar's national security strategy (Kamrava, 2011). Given this, it makes it easier for Qatar to gain influence in strategic areas.

In mediation, confidentiality is still a key element. As a good mediator, Qatar has several characteristics, namely impartiality, leverage, integrity, empathy, patience, independence, flexibility, and negotiation skills. These characteristics are owned by Qatari diplomats such as Emir, Prime Minister Hamad bin Jassim, Deputy Minister Al-Mahmud. Therefore, Qatar is very clever in conflict mediation, not conflict resolution. For Qatar, mediation is a process that avoids negative things and the destructive consequences of violent conflictual behavior.

Secondly, efforts to overcome the crisis disinformation that he is experiencing, Qatar is building information connectivity by capitalizing the development of information technology and the internet has given a greater diplomatic concept. Modern diplomacy is the result of world change after World War 2 (Amini \& Akbarsefat, 2016). In this age of globalization it can be said that there has been an increase in the role of the media and non-governmental actors. Al-Jazeera is referred to as a benchmark of Qatar's foreign policy. Al-Jazeera's role has effectiveness in Qatar diplomacy. Qatar's political bargaining power has increased in the last decade in the international system. Al-Jazeera's media channel can be said to be a diplomatic tool for Qatar, and where this media has a significant influence in the Middle East region. Al- 
Jazeera's media is able to create the image of Qatar and the world public opinion. With the role of the media, Qatar became a major actor in the region.

Al-Jazeera's media is able to create the image of Qatar and the world public opinion. With the role of the media, Qatar became a major actor in the region. Qatar is able to align itself with major actors in the Middle East region, namely Saudi Arabia and Iran, as well as emerging power, namely Turkey. Therefore, Qatar has a very active policy. This can be seen in support to resolve the problems between the Libyan rebels and the Gaddafi regime, the Yemeni rebels with the Ali Abdollah Saleh regime, the Asad regime with Sheikh Yusuf al-Qaradawi, the Muslim Brotherhood with the Jewish regime, and the Persian Gulf countries and Iran (Amini \& Akbarsefat, 2016).

Al-Jazeera's media is able to create an open media atmosphere, so that it can attract the attention of the public and intellectuals about what is happening in the Middle East and the Arab world. So it is not surprising that Qatar is very active in diplomacy and is a mediator for conflict resolution. Qatar succeeded in conducting general diplomacy prioritizing its foreign policy (Samuel-Azran, 2013).

Third, Qatar prefers to use soft power in the practice of diplomacy. Qatar prefers to focus on higher education systems and exchange programs. In addition, he also has a national strategy that is sustaining economic development with education at the center. This can be seen in the Qatar National Development Strategy 2011-2016, where Qatar has educational goals, namely (1) an effective system for financing scientific research carried out by the public and private sectors and holding international organizations and becoming an international research center; (2) has a strong international role in cultural and intellectual activity as well as scientific research (Felsch, 2016). The Qatar Foundation also sponsors the FC Barcelona shirt and invests in the Doha Campus, often called Education City, which has six branches in American, British and French universities. All of this was done to enhance Qatar's reputation and legitimacy internationally. This shows that Qatar is increasing its soft power strategy.

One measure of the success of this strategy is the large number of foreign students studying in Qatar. This also shows that Qatar has a very attractive culture. With the exchange there will be communication with residents from outside Qatar where this will form a "family" and mutual understanding, which of course will form easier political cooperation between Qatar and other countries and reduce the incidence of armed conflict.

Qatar is the destination country for continuing higher education and migrant workers. This shows the interest of foreign people towards Qatari culture. Qatar provides migrant workers with very high salaries and generous benefits. Migrants who return to their home countries will naturally spread positive effects on Qatar (Felsch, 2016). This is different from Arab countries. Qatar's reputation is better than Arabic according to migrant workers. In this case Qatar demonstrates the practice of carrot 
diplomacy, that he can attract migrants to work in Qatar because he provides some great benefits for migrants. This shows that Qatar is able to use soft power properly.

Aside from education and migrant workers, Qatar also made itself the host of the FIFA World Cup 2022. If Qatar succeeds in holding this tournament, it will certainly enhance Qatar's international reputation through the influence of global media, so that it can attract many tourists to enter to Qatar. As the host of the FIFA World Cup 2022 it can be said that Qatar formed a national strategy in investing in sporting events, which have political objectives (Felsch, 2016).

The three major steps are by capitalizing a positive self-image on the issue of peace, using the power of information to neutralize disinformation about Qatar, and the choice to use the issue of soft power in the matter of providing employment with a high reward system that allows Qatar to manage the crisis well. This step is an articulation of the idea of clean diplomacy, diplomacy that is consistent with national and international norms, and is carried out with the principles of openness, fairness and integrity.

\section{Conclusion}

Qatar is a small country, but it is very active in making foreign policy to make it a legitimate actor in the international arena. At present, Qatar is often called the increasingly powerful actor in the international system. As a small country, it uses soft power more than using hard power. For Qatar, using soft power capabilities is more beneficial and results in effectiveness. The ultimate goal of Qatar's foreign policy agenda is security. This is because he is very vulnerable to pressure from neighboring countries that are classified as large countries namely Saudi Arabia and Iran.

As a small country that is experiencing an international political crisis, Qatar is the best example. Mediation is one of the main pillars of Qatar's foreign policy. Qatar is a peacemaker in both a war and international conflict. Branding as a good country and state is what later became an important factor Qatar was able to get out of the regional political and economic crisis effectively.

Being a mediator is a survival strategy for Qatar. Mediation is a central tool to improve the soft power and global image of Qatar. Although as a small country, he also wants to be a country that has significant influence in the international world. Qatar's mediation efforts in resolving a conflict are very impressive for the international world. So becoming a mediator, is one way of national security strategy and diplomacy carried out by Qatar. This is a form of clean diplomacy by Qatar. This strategy is the safest strategy for Qatar in conducting diplomacy practices in the international world.

\section{Reference}

Amini, A., \& Akbarsefat, M. (2016). Qatar's Modern Diplomacy and Al-Jazeera’s Role 
in Middle East's Evolutions over the Recent Decades. Journal of Sociological Research, 7(1), 123-137. https://doi.org/10.5296/jsr.v7i1.9580

Blanchard, C. M. (2014, November 4). Qatar: Background and U.S. Relations. Congrrssional Research Service. Retrieved from https:// fas.org/sgp/crs/mideast/RL31718.pdf

Chong, A. (2006). Singapore's foreign policy beliefs as "Abridged Realism": Pragmatic and liberal prefixes in the foreign policy thought of Rajaratnam, Lee, Koh, and Mahbubani. International Relations of the Asia-Pacific, 6(2), 269-306. https://doi.org/10.1093/irap/lci137

Felsch, M. (2016). Qatar's Rising International Influence: A Case of Soft Power? Conjuntura Internacional, 13(1), 22-35. https://doi.org/10.5752/p.18096182.2016v13n1p22

Gabriel, J. M., \& Fischer, T. (2003). Swiss foreign policy, 1945-2002. Palgrave Macmillan.

Harlow, W. F. (2017). Strategic Silence as a Frame for Understanding the 2017 Embargo Against Qatar. Journal of Contemporary Rhetoric (Vol. 7). Retrieved from http://gulfnews.com/news/uae/uae-supports-statements-of-bahrain-andsaudi-arabia-on-qatar-1.2038529

Himes, A. (2018). Competing visions for a modern emirate: The government centre of the state of Qatar. International Journal of Islamic Architecture. https://doi.org/10.1386/ijia.7.1.143_1

Jones, M. O., Lynch, M., Roberts, D., \& Diwan, K. S. (2017). The Qatar Crisis. Project on Middle East Political Science (POMEPS) Briefings. Retrieved from https://pomeps.org/wpcontent/uploads/2017/10/POMEPS_GCC_Qatar-Crisis.pdf

Kamrava, M. (2011). Mediation and Qatari Foreign Policy. Middle East Journal, 65(4), $539-556$.

Leifer, M. (2000). Singapore's Foreign Policy, Coping with Vulnerability. New York: Routledge.

Lian Kwen Fee. (2001). The construction of Malay identity across nations Malaysia, Singapore, and Indonesia. Bijdragen Tot de Taal-, Land- En Volkenkunde / Journal of the Humanities and Social Sciences of Southeast Asia, 157(4), 861-879. https://doi.org/10.1163/22134379-90003795

Low, L. (2002). Globalisation and the Political Economy of Singapore's Policy on Foreign Talent and High Skills. Journal of Education and Work, 15(4), 409-425. https://doi.org/10.1080/1363908022000023551

Miller, R. (2019). Managing Regional Conflict: The Gulf Cooperation Council and the Embargo of Qatar. Global Policy, 10(S2), 36-45. https://doi.org/10.1111/1758-5899.12674

Miller, R., \& Verhoeven, H. (2019). Overcoming smallness: Qatar, the United Arab Emirates and strategic realignment in the Gulf. International Politics, 20(98), 120. https://doi.org/10.1057/s41311-019-00180-0

Mitchell, J. S. (2014). Book Review Qatar: small state, big politics. Democratization, 21(4), 771-773. https://doi.org/10.1080/13510347.2013.876994

Nuruzzaman, M. (2015). Gulf Cooperation Council (GCC), Qatar and dispute mediations: a critical investigation. Contemporary Arab Affairs, 8(4). https://doi.org/10.1080/17550912.2015.1078073 
Samuel-Azran, T. (2013). Al-Jazeera, Qatar, and New Tactics in State-Sponsored Media Diplomacy. American Behavioral Scientist, 57(9), 1293-1311. https://doi.org/10.1177/0002764213487736

Ulrichsen, K. C. (2014). Qatar and the Arab Spring: Policy Drivers and Regional Implications (September 2014). Carnegie Endowment for International Peace. Retrieved from https://carnegieendowment.org/files/Brief-Ulrichsen_Qatar.pdf

Warsito, T., \& Surwandono, . (2015). "Diplomasi Bersih" Dalam Perspektif Islam. THAQAFIYYAT: Jurnal Bahasa, Peradaban Dan Informasi Islam, 16(2), 145176. Retrieved from http://ejournal.uinsuka.ac.id/adab/thaqafiyyat/article/view/627/pdf_32

Zafirov, M. (2017). The Qatar Crisis-Why the Blockade Failed. Israel Journal of Foreign Affairs, 11(2), 191-201. https://doi.org/10.1080/23739770.2017.1382072 